$$
\text { recenze }
$$





\section{Čtenářům. S láskou}

TRÁVNÍČEK, Jiří. Česká čtenářská republika: generace, fenomény, životopisy. Brno: Host, 2017, 447 s., ISBN 978-80-7491-850-6

Text lze dopodrobna číst, literárněvědně zkoumat, podrobit jej kritice, pokusit se o jeho interpretaci. Avšak co jeho čtenář - prvek literatury tolik důležitý, avšak literární vědou - často i samotnými autory - mnohdy opomíjený? Čtenár̆, bez něhož by literatura nutně ztratila část svého smyslu?

Literární vědec a akademik Jiří Trávníček se rozhodl seznámit a vzájemně přibližit čtenáře a literární vědu pomocí výzkumu čtenářství. Jeho cílem bylo napsat knihu o čtenářích, ,a to o čtenářích napřič celou současnou společností, tj. o čtenářích běžných; nikoli tedy pouze o těch, kdo se cítí být ke čtení poutáni nějakou obzvláště silnou vazbou, ani o těch, kdo čtou jen beletrii; nejde zde ani o lidi profesionálně se čtením spoutané“1, a na důkaz této své náklonnosti publikaci následně čtenářům věnovat.

Autor se pokouší zmapovat současnou českou čtenářskou kulturu - její rozsah, strukturu. Proto se na čtenáře dívá ze tří různých perspektiv, které zároveň zachycuje podtitul knihy: generace (představuje současné čtyři generace př́iznačně nazvané rozhlasová, televizní, počitačová a internetová), fenomény (věnuje pozornost podstatným jevům, jakýmsi průsečíkům, např́iklad Nedočteno, Předčitání, Učitelé) a životopisy (konkrétní výpovědi, řekněme čtenářské kazuistiky).

Jiří Trávníček se čtenářům věnuje dlouhodobě - zkoumá čtenářství kvantitativně (statisticky) i kvalitativně (pomocí čtenářských životopisů), výsledky svých výzkumů pravidelně publikuje. Je tedy zřejmé, že je v této oblasti autorem nadmíru zkušeným, sebejistým, což Česká čtenářská republika potvrzuje. V úvodu textu zapáleně („moja ukochana Polska!“) popisuje své inspirační

1) TRÁVNÍČEK, Jiří. Česká čtenářská republika: generace, fenomény, životopisy. Brno: Host, 2017, ISBN 978-80-7491850-6, s. 15. 
zdroje a mimochodem tak představuje část vlastního čtenářského životopisu - metody, kterou má brilantně osvojenou a plně mu slouží.

Jádro České čtenářské republiky totiž tvoří právě 138 čtenářských životopisů výpovědí narátorů, které byly nahrány a přepsány v průběhu sedmi let (2009-2015). Trávníček představuje přednosti této metody jakožto podmnožiny životopisného vyprávění, které „pokud je vhodně podníceno zvnějšku, umí rozvázat jazyk, je s to vyvolat v život věci, jež by jinak zůstaly zasuty “2. Použitý postup vědecky ukotvuje pečlivým popisem metodiky, podle níž, spolu s dalšími tazateli, pracoval (výběr narátorů, osnova rozhovorů, jejich nahrávání a následný přepis).

V části nazvané Generace autor nahlíží na jednotlivé generace čtenářů, a to nikoli pouze prizmatem čtenářské kultury ( $\mathrm{k}$ té je pozornost obrácena zákonitě a plynule sama). Autorovi se daří pracovat $\mathrm{v}$ širším kontextu: uživá množství historických a společenských zdrojů, text prokládá citacemi samotných respondentů, které citlivě komentuje. Výsledkem je unikátní text, jenž přináší všestranný pohled na generace současné české populace.

Část Fenomény je věnována abecedně řazeným jevům, které se $\mathrm{v}$ průběhu výzkumu opakovaly a jež si autor sám „vyzvětšil“. Trávníček se ukazuje jako bystrý a vtipný znalec a glosátor naší čtenářské kultury (kapitolu Babička zahajuje větou „Ta aby tady chyběla! “33). Je mimořádně empatický, čtenáře se snaží pochopit, nikdy ani náznakem neodsuzuje. Aktivně usiluje přijít na kloub různým „záhadám“, což dodává textu detektivní, místy až populárně-naučný ráz (proč je u Češek tolik oblíbená BettyMacDonaldová, proč nás poezie v určitém věku většinou přestává bavit, má souboj kniha vs. film vítěze, kdy a proč se Štětináč stává sympatičtějším než Mirek Dušín atd.).

$\mathrm{V}$ části knihy věnované samotným čtenářským životopisům je uvedeno osm životopisů v kompletní podobě. Ty by byly bezpochyby čtivé samy o sobě - autor jejich čtivost však umocňuje pojmenováním čtenářů jako jednotlivých biologických druhů tvora „čtenář“ (čtenář celoživotně soustavný a přemýšlivý, čtenářka soustavná a zorientovaná, čtenář restartovaný atd.) a krátkým perexem: naznačujícím, navnad’ujícím.

2) TRÁVNÍČEK, Jiří. Česká čtenářská republika: generace, fenomény, životopisy. Brno: Host, 2017, ISBN 978-80-7491850-6, s. 41.

3) Tamtéž, s. 161.

4) Opět zásluhou autora a jeho spolupracovníků - tazatelů -, nebot’ za takto čtivými rozhovory nutně musí stát mimořádně empatický tazatel, který nenápadně povzbuzuje narátory upřímným a stálým vyjadřováním svého zájmu... 
V závěru Trávníček výsledky shrnuje, a to jak obšírněji za pomoci interdisciplinárních přesahů (např. koncept omnivorousness, fráze épater le bourgeois atd.), tak ve formě několika krátkých shrnutí. Zde nutno podotknout, že autorovi se podařilo podstatné výsledky výzkumu přetavit v úderná fakta, aniž by je přitom musel jakkoliv zjednodušovat.

Česká čtenářská republika je publikace v mnoha ohledech unikátní; unikátní byl však i samotný výzkum, jehož je tento text výsledkem a s nímž má tedy zákonitě mnoho společného. Jiří Trávníček je jako výzkumník i autor zcela konzistentní: píše tak, jak zkoumá. Jde naproti svým narátorům i čtenářům; snaží se je pochopit, obhájit, projevit zájem. Českou čtenářskou republiku prokládá grafy, fotografiemi, statistikami, vtipy, oživujícími přirovnáními („při jeho poslechu [rádia, pozn. aut.] si mluvené slovo jako bankovku musíme teprve směnit za [vizuální] představu“5) a pochopitelně fakty. Trávníček dokazuje, že nejen texty a jejich autoři, ale i čtenáři jsou důležitým předmětem literárněvědného zkoumání. A jako takoví si zaslouží, aby se o nich mluvilo a psalo - tak, jak to dělá Jiří Trávníček - s láskou.

Marie Mokrá

5) TRÁVNÍČEK, Jiří. Česká čtenářská republika: generace, fenomény, životopisy. Brno: Host, 2017, ISBN 978-80-7491850-6, s. 208. 
